\title{
IMPLEMENTASI STRATEGI E-MARKETING BERBASIS WEB (STUDI KASUS: PERUSAHAAN KATERING DAN DEKORASI)
}

\author{
Johni S. Pasaribu' ${ }^{1}$, Ardi Taryanto \\ ${ }^{1,2}$ Program Studi Manajemen Informatika, Politeknik Piksi Ganesha Bandung, Bandung, Indonesia \\ *Email: johni_0106@yahoo.com, ardipiksi@yahoo.com
}

\begin{abstract}
The purpose of research is to produce a model of e-marketing strategies in order to identify the existing problems faced by the company and to identify its weaknesses. Additionally, this research designs a web based Marketing system. The development of the Internet improvethe way of doing business from traditional to electronic, no denying that the economic activity leading to the marketing of electronic. The system has been designed to give facilitation for customer to get information abaut material of tutorial activity fast and efficient. The methodologies used are literature study, observation, interview, analysis and design with seven-stages marketing internet. It is concluded that e-Marketing system that has been designed supports information access easily and fast. The e-Marketing application consists of features such as Online Register, Contact us, Download, News, and Complaint. It is expected to help deliver and maintain customer satisfaction by building a close relationship to the customers.
\end{abstract}

Keywords: E-marketing, Facilitation, Information, Customer satisfaction

\section{PENDAHULUAN}

Perkembangan internet yang sangat cepat sangat mempengaruhi perubahan bisnis. Banyak aktivitas bisnis yang berubah dengan tersedianya internet saat ini. Perubahan aktivitas bisnis yang signifikan dipengaruhi oleh internet salah satunya adalah pemasaran/marketing. Pemasaran adalah proses sosial dan manajerial dimana individu dan grup memperoleh apa yang mereka inginkan dan butuhkan melalui penciptaan dan pertukaran produk dan nilai dengan orang lain (Kotler \& Amstrong, 2004). Pemasaran juga merupakan proses dari perancangan dan pelaksanaan konsepsi, harga, promosi dan distribusi dari ide, barang dan layanan untuk menciptakan pertukaran yang memuaskan individu dan tujuan organisasi (Mohammed et al., 2003). Konsep internet yang tidak memiliki batasan tempat dan waktu, semakin memudahkan perusahaan dalam memberikan informasi produknya. Sistem pemasaran produk melalui internet ini lebih sering didengar dengan istilah e-marketing. E-marketing menggambarkan usaha-usaha perusahaan untuk menginformasikan, berkomunikasi, mempromosikan dan memasarkan produk dan jasa melalui internet (Kotler \& Armstrong, 2004). Electronic marketing memanfaatkan teknologi jaringan untuk mengkoordinasi penelitian pangsa pasar, membantu pengembangan produk, mengembangkan strategi dan taktik untuk memikat pelanggan, menyediakan distribusi online, mempertahankan catatan pelanggan, menciptakan kepuasan pelanggan, dan mengumpulkan umpan balik pelanggan (Reedy, Schullo \& Zimmerman, 2000).

E-marketing merupakan bagian dari e-commerce yang merupakan sistem perdagangan melalui internet, di mana internet akan terus memberikan sifat yang up to date, maka perusahaan dapat memberikan layanan informasi produk yang ditawarkan secara jelas dan mudah. Hal ini akan memberikan dampak yang baik untuk kemajuan perusahaan jika sistem ini bisa dijalankan dengan baik. Selain itu e-marketing juga merupakan bagian dari e-CRM dimana pengelolaan hubungan dengan pelanggan salah satunya melalui kegiatan pemasaran. E-marketing banyak dilakukan untuk meningkatkan brand image perusahaan karena membuat perusahaan selalu diingat oleh pelanggannya (top of mind). Emarketing banyak memberikan kemudahan dan keuntungan lebih bagi perusahaan, pelanggan dan rekanan bisnis dari perusahaan. Pemilihan strategi $e$ - marketing yang cocok dengan perusahaan dan mengetahui detil cara dan dampak penerapannya sangat penting dan diperlukan oleh perusahaan. Sangat penting bagi perusahaan untuk memasarkan dan memperkenalkan produk secara online dalam bentuk website yang merupakan salah satu faktor penting dalam pemasaran pada Nesha Catering Service and Decoration.

Nesha Catering Service and Decoration merupakan perusahaan yang bergerak dalam bidang penjualan jasa katering dan dekorasi memerlukan website guna menunjang pemasaran produk-produk mereka. Namun perusahaan tidak cukup hanya mengandalkan sistem dan teknologi informasi untuk dapat mencapai keunggulan dan mempertahankan posisi perusahaan di antara para pesaingnya, untuk itu perusahaan harus didukung oleh sebuah strategi pemasaran yang baik dan tepat. Dengan adanya perencanaan strategi pemasaran, maka fokus dalam perusahaan menjadi terarah dan terpenuhi yang akan 
mendukung semua fungsi bisnis yang ada pada perusahaan, sehingga tujuan dan sasaran bisnis perusahaan dapat tercapai.

Adapun tujuan penelitian ini adalah merancang sistem pemasaran serta penjualan produk terbaru di Nesha Catering Service and Decoration guna memperbaiki permasalahan-permasalahan yang terjadi pada sistem yang sedang berjalan dan mengembangkan sistem e-marketing untuk memberikan informasi produk secara detail. Dalam penelitian dibatasi pada sistem informasi produk yang masih tersedia berikut harganya, sistem tidak menyediakan pembayaran selain dengan mata uang rupiah, sistem hanya menyediakan pembayaran booking fee, dan penggunaan sistem tidak bisa dilakukan secara offline.

Metode yang digunakan dalam penelitian berdasarkan metoda ilmiah dengan cara observasi (Observation. Pendekatan untuk mendapatkan data primer dengan cara mengamati langsung obyek data, wawancara (interview), pendekatan komunikasi (communication approach) yang berhubungan langsung dengan sumber data, dan studi pustaka mengumpulkan data-data dan informasi yang berasal dari bukubuku, dokumen dan internet.

\section{MATERI DAN METODE}

\subsection{Pemasaran}

Pemasaran adalah proses yang meliputi beberapa elemen yang terlihat tidak terhubung satu dengan yang lain, tetapi pada kenyataannya elemen tersebut saling terhubung dan membentuk relasi antara produser atau manufaktur dengan konsumen (Fatayerji, 2004, p25)\

\subsection{Manajemen Pemasaran dalam E-Marketing}

Manajemen Pemasaran adalah sebagai seni dan ilmu dalam memilih target pasar dan mendapatkan, menjaga, dan meningkatkan jumlah pelanggan dengan menciptakan, menyampaikan, dan mengkomunikasikan nilai pelanggan superior.

\subsection{Analisis Situasi}

Analisis SWOT merupakan sebuah metode perencanaan strategis yang digunakan untuk mengevaluasi kekuatan, kelemahan, peluang, dan ancaman dalam suatu proyek atau suatu spekulasi bisnis

\subsection{Desain Web}

Desain Web adalah jenis desain grafis yang ditujukan untuk pengembangan dan styling obyek lingkungan informasi Internet untuk menyediakan dengan fitur konsumen high-end dan kualitas estetika. Definisi yang ditawarkan memisahkan desain web dari pemrograman web, menekankan fitur fungsional dari sebuah situs web, serta desain posisi web sebagai semacam desain grafis

\subsection{Bahasa Pemrograman}

a. HTML (HyperText Markup Language) adalah sebuah bahasa markup yang digunakan untuk membuat sebuah halaman web dan menampilkan berbagai informasi di dalam sebuah browser Internet

b. PHP (Personal Home Page) adalah bahasa pemrograman script yang paling banyak dipakai saat ini. PHP pertama kali dibuat oleh Rasmus Lerdorf pada tahun 1995.

c. CSS (Cascading Style Sheet) merupakan suatu bahasa program web yang digunakan untuk mengendalikan dan membangun berbagai komponen dalamn web yang digunakan untuk mengendalikan dan membangun berbagai komponen dalam web sehingga tampilan web akan lebih rapi, terstruktur dan seragam.

d. XAMPP adalah perangkat lunak bebas, yang mendukung banyak sistem operasi, merupakan kompilasi dari beberapa program. Fungsinya adalah sebagai server yang berdiri sendiri (localhost), yang terdiri atas program Apache HTTP Server, MySQL database, dan penerjemah bahasa yang ditulis dengan bahasa pemrograman PHP dan Perl.

e. Adobe Dreamweaver merupakan program penyunting halaman web dari Adobe Systems yang dulu dikenal sebagai Macromedia Dreamweaver dari Macromedia. Program ini banyak digunakan oleh pengembang web karena fitur-fiturnya yang lengkap serta kemudahan dalam penggunaannya 


\subsection{Metode}

Analisis dan perancangan dilakukakan berdasarkan tujuh tahapan internet marketing ("Mohammed et al (2006), p8-18) yaitu :

Tahap 1 : membentuk peluang pasar (framming the market opportunity)

Tahap 2 : memformulasikan strategi pemasaran (formulating the marketing strategy)

Tahap 3 : mendesain pengalaman konsumen (designing the customer experience)

Tahap $4 \quad$ : merancang tampilan untuk konsumen (crafting the customer interface)

Tahap 5 : merancang program pemasaran (designing the marketing program)

Tahap 6 : pengadaan informasi konsumen melalui teknologi (leveraging customer information through technology)

Tahap 7 : mengevaluasi program pemasaran (evaluating marketing program)

Dalam penelitian analisis sistem yang sedang berjalan dilakukan melalui tahapan 1, 2 dan 3 kemudian mengidentifikasikan kebutuhan informasi perusahaan. Selanjutnya membangun hubungan antar muka dengan tahapan 4, 5, 6 dan 7. Pembuatan UML diagram meliputi rich picture, class diagram, use case diagram, overview activity diagram dan navigation diagram.

\section{a. Analisis Sistem Yang Berjalan}

Perangkat lunak yang akan dibangun dalam tugas akhir ini adalah sebuah aplikasi E-Marketing di Nesha Catering Service and Decoration berbasis web yang dapat membantu dalam menyampaikan informasi produk kepada konsumen tanpa mengharuskan konsumen datang langsung ke Nesha Catering Service and Decoration untuk melakukan pemesanan paket catering dan dekorasi pernikahan.

Perangkat lunak ini digunakan oleh admin dan konsumen dimana seorang admin bertugas untuk mengontrol pemesanan konsumen. Admin mempunyai hak penuh terhadap sistem yang mengelola data informasi tentang Nesha Catering Service and Decoration yang meliputi pengelolaan data konsumen, kategori produk, penambahan data paket catering dan dekorasi serta data konsumen yang telah melakukan pemesanan. Sedangkan konsumen berhak melakukan pemesanan setelah mendaftarkan diri sebagai member. Konsumen hanya memiliki hak akses untuk mengedit data diri masing-masing sesuai akunnya, melakukan pemesanan dan memperoleh laporan pemesanan yang tela dipesan.

Salah satu tahapan analisis sistem yaitu tahapan yang memberikan gambaran tentang sistem yang sedang berjalan saat ini. Analisis ini bertujuan untuk memberikan gambaran bagaimana cara kerja dari sistem yang sedang berjalan. Prosedur yang sedang berjalan saat ini yaitu proses informasi pemesanan catering dan dekorasi. Proses informasi catering dan dekorasi di Nesha Catering Service and Decoration adalah sebagai berikut:

1) Cara pemesanan yang mengharuskan konsumen datang langsung ke Nesha Catering Service and Decoration untuk melakukan pemesanan catering dan pemilihan dekorasi pernikahan.

2) Konsumen akan mendapatkan informasi catering dan dekorasi pernikahan yang diberikan oleh Nesha Catering Service and Decoration.

3) Pemesanan catering dan dekorasi yang mengharuskan kembali datang ke Nesha Catering Service and Decoration untuk menentukan tanggal pemesanan.

4) Nesha Catering Service and Decoration akan menyanggupi atau tidak untuk menerima pesanan pada tanggal tersebut. Nesha Catering Service and Decoration dapat menyatakan tidak dapat menyanggupi pesanan jika sedang banyak pesanan pada tanggal tersebut. Jika Nesha Catering Service and Decoration tidak menyanggupi pemesanan konsumen, maka konsumen dapat membuat pesanan untuk tanggal lain.

5) Jika Nesha Catering Service and Decoration menerima, maka akan mencatat informasi detail untuk pesanan catering atau dekorasi dari konsumen. Data detail yang diminta berupa anggaran, menu catering atau dekorasi dan catatan lain yang dibutuhkan untuk kepentingan pesanan konsumen.

6) Setelah pesanan di catat, menghasilan dokumen catatan pesanan konsumsen yang di arsipkan Nesha Catering Service and Decoration.

7) Kemudian konsumen dan Nesha Catering Service and Decoration akan membuat kesepakatan mengenai nego harga, pembayaran, dan pemesanan. Jika belum ada kesepakatan, konsumen dapat membuat kesepakatan kembali

8) Jika kedua belah pihak sepakat, maka konsumen akan melakukan pembayaran booking fee sebagai tanda jadi. 
9) Konsumen mendapat kwitansi pembayaran booking fee. Kwitansi pembayaran diarsipkan oleh Nesha Catering Service Service and Decoration.

10) Nesha Catering Service and Decoration akan mengerjakan pesanan konsumen pada tanggal yang ditentukan.

11) Konsumen menerima hasil pekerjaan yang di kerjakan Nesha Catering Service and Decoration.

12) Konsumen membayar sisa pembayaran dan menerima kwitansi pembayaran lunas.

13) Nesha Catering mengarsipkan tanda bukti pembayaran lunas dan selesai. Flowmap sistem yang berjalan disajikan pada Gambar 1.

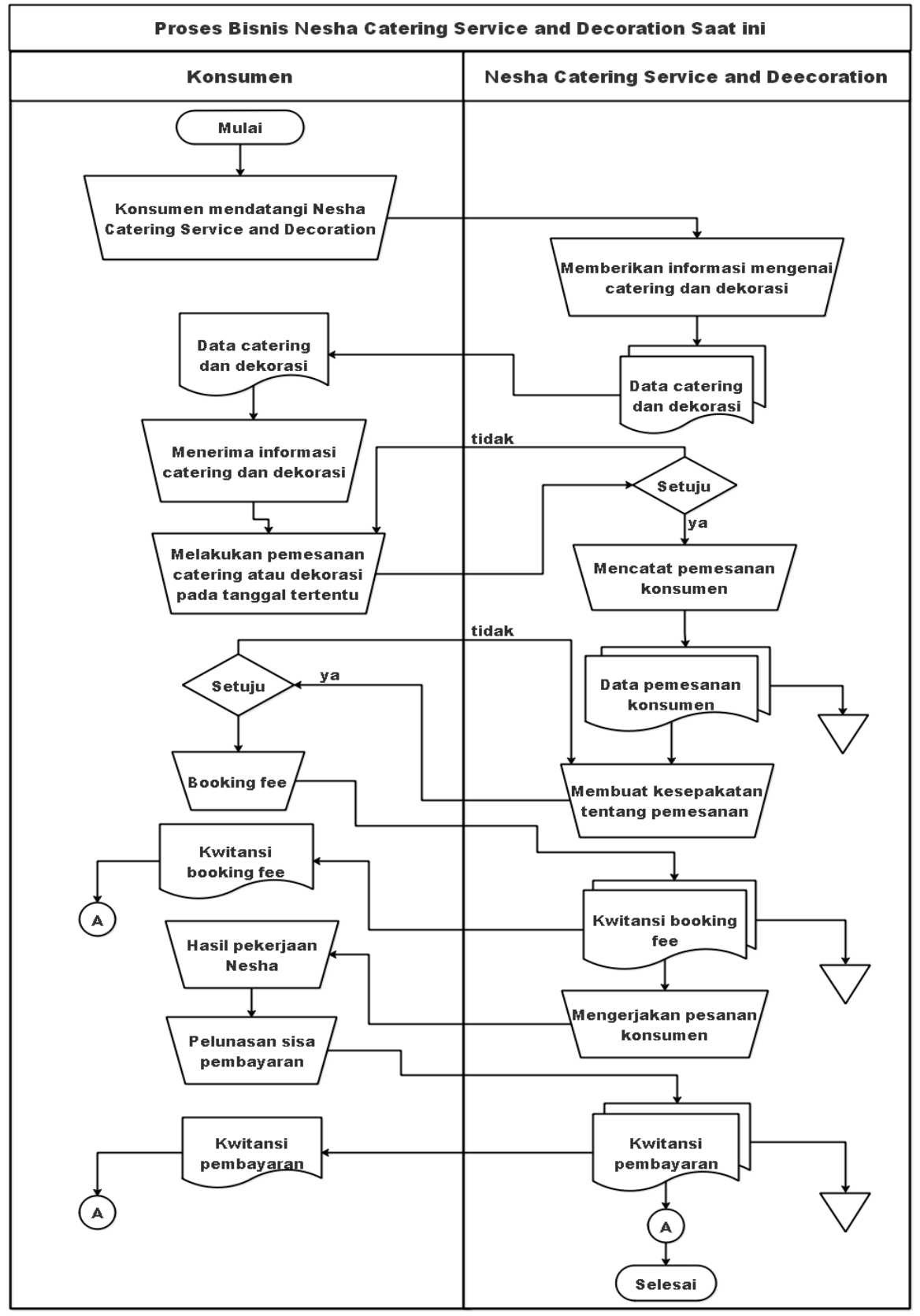

Gambar 1. Flowmap Sistem Yang Berjalan

\section{b. Analisis Sistem Yang Diusulkan}

Berdasarkan hasil analisis yang sedang berjalan maka dapat di simpulkan bahwa perlu adanya media informasi promosi dan penjualan produk guna mempermudah konsumen untuk mengetahui produk - 
produk yang ada di Nesha Catering Service and Decoration. Flowmap yang diusulkan disajikan pada Gambar 2.

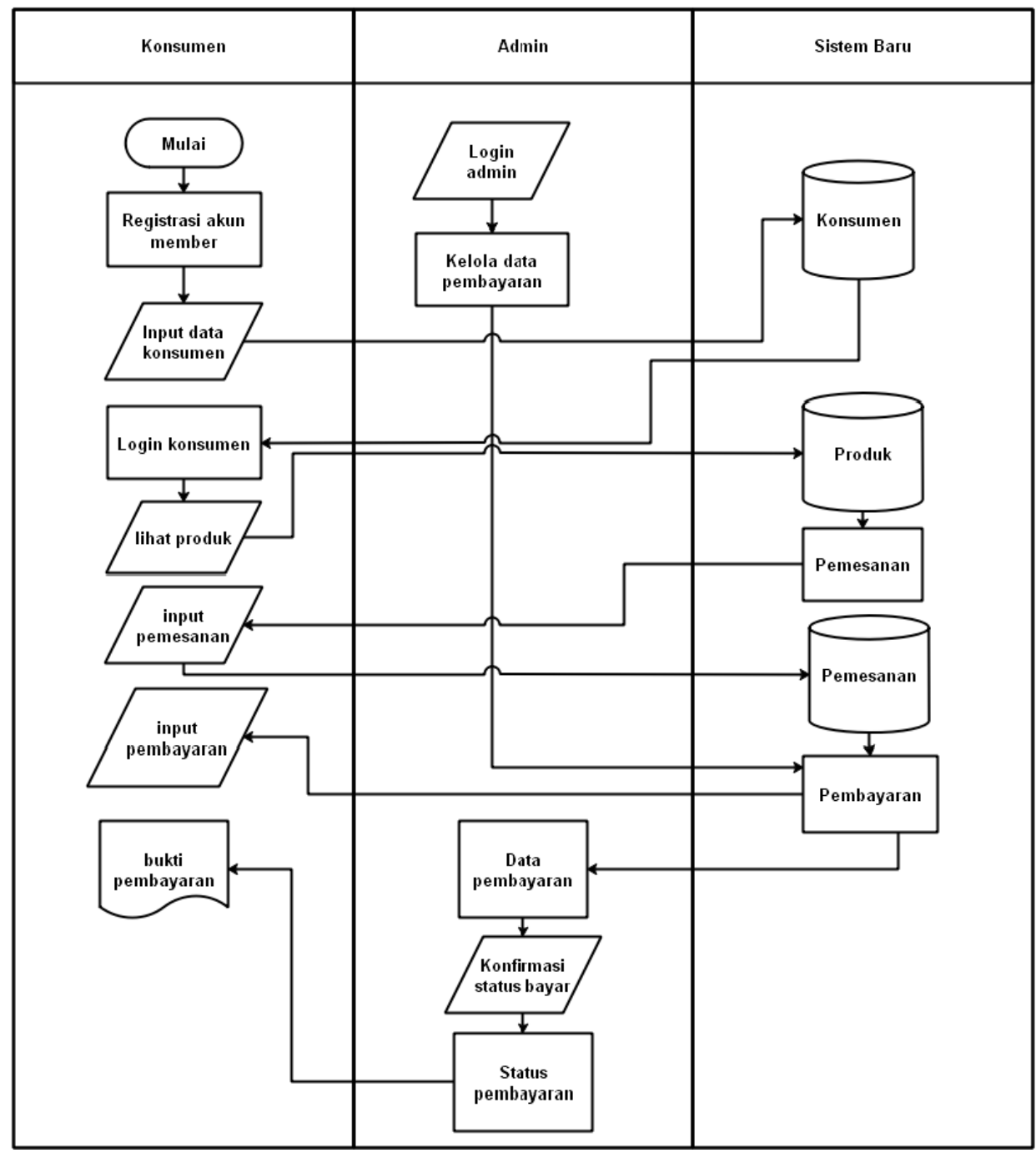

Gambar 2. Flowmap Sistem Yang Diusulkan

Berikut adalah analisis sistem yang diusulkan pada Nesha Cartering Service and Decoration :

1) Konsumen melakukan login untuk melakukan pemesanan, konsumen yang belum memiliki akun diharuskan untuk melakukan registrasi terlebih dahulu.

2) Konsumen memilih produk yang sudah ada untuk melakukan pemesanan dan akan masuk ke keranjang pemesanan.

3) Konsumen melakukan pembayaran booking fee untuk pemesanan yang telah dipesan.

4) Sistem secara otomatis mengirimkan invoice ke halaman konsumen.

5) Konsumen mencetak invoice sebagai tanda bukti pembayaran booking fee.

6) Admin akan mengecek data pembayaran yang telah di lakukan oleh konsumen.

7) Jika pembayaran telah di lakukan, maka admin akan merubah status pemesanan menjadi booking.

\section{c. Entity Relationship Diagram}

Komponen pada entity relationship diagram berupa himpunan entitas dan himpunan relasi. Komponen akan di transformasikan menjadi tabel-tabel. Atribut pada diagram entity relationship dinyatakan sebagai field dari tabel. Diagram entity relationship dari sistem $e$ marketing di Nesha Catering Service and Decoration seperti disajikan Gambar3. 


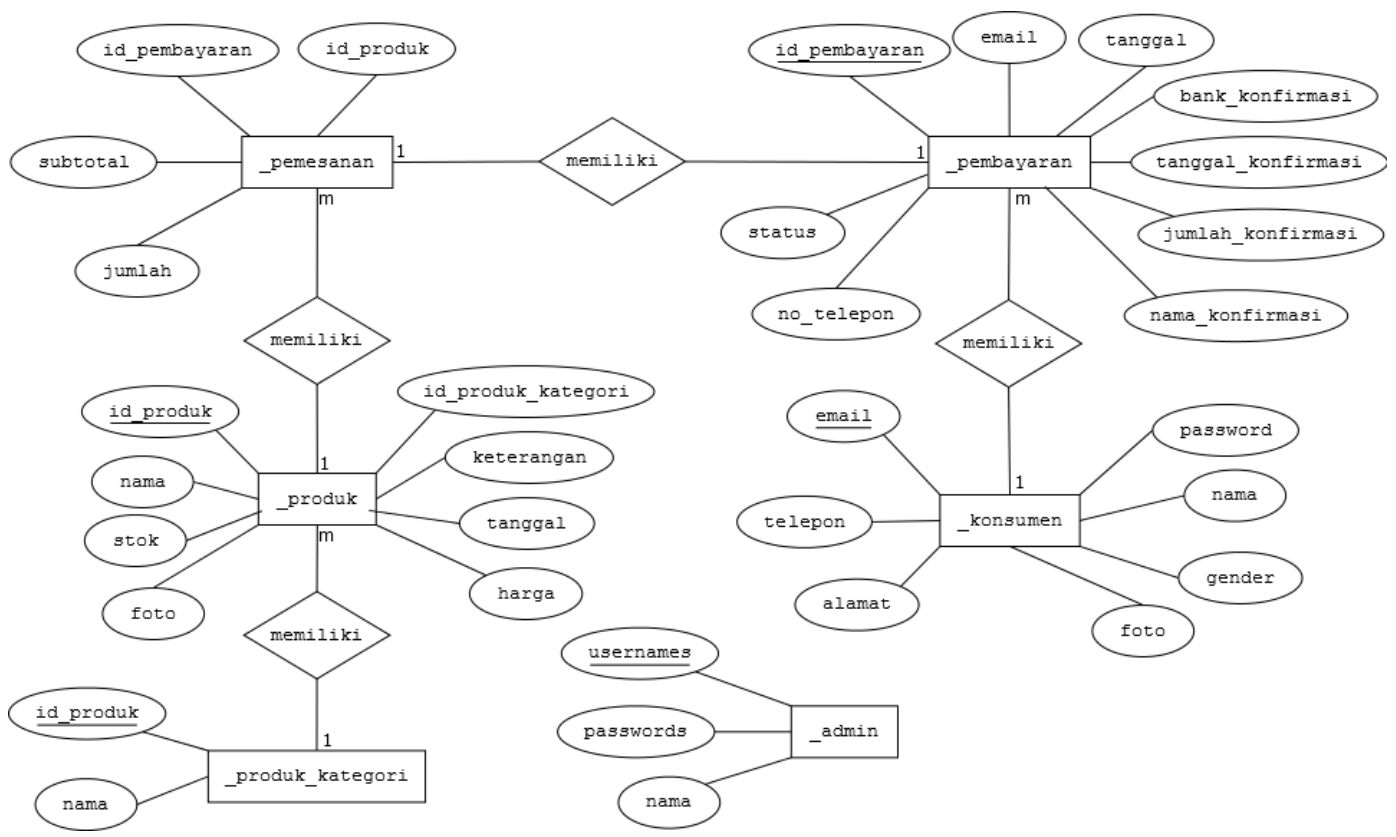

Gambar 3. Entity Relationship Diagram Nesha Catering Service and Decoration

\section{d. Skema Relasi}

Pada sub bab ini akan dijelaskan mengenai penjabaran lebih lanjut dari Entity Relationship Diagram (ERD) ke dalam Conceptual Data Model (CDM) yang merupakan suatu proses dimana elemen-elemen data di kelompokan menjadi tabel - tabel dan dalam tabel tersebut terdapat entitas - entitas serta relasi antar entitas tersebut. Conceptual Data Model dari sistem e-marketing di Nesha Catering Service and Decoration disajikan pada Gambar 4.

\begin{tabular}{|c|c|}
\hline \multicolumn{2}{|c|}{ admin } \\
\hline PK & usernames \\
\hline & $\begin{array}{c}\text { passwords } \\
\text { nama }\end{array}$ \\
\hline
\end{tabular}
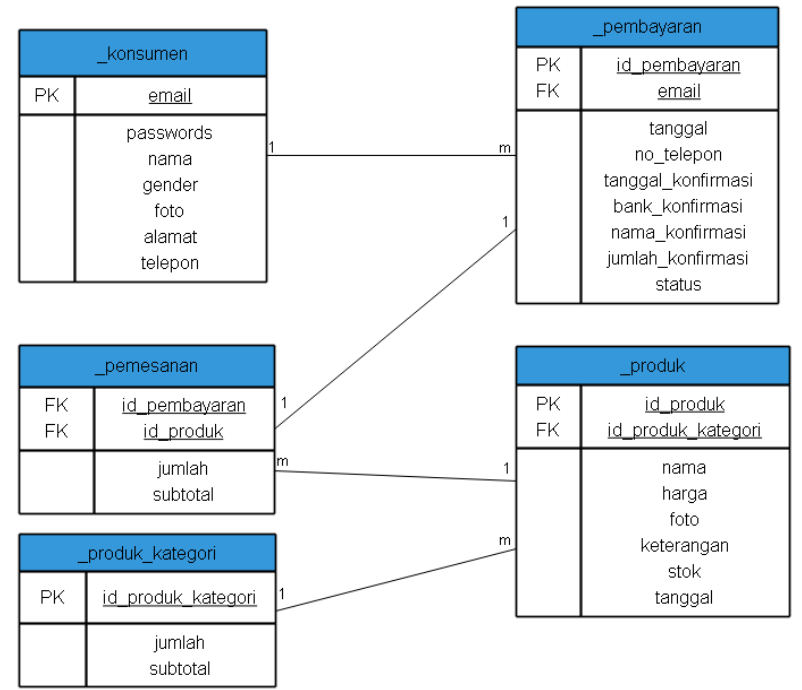

Gambar 4. Conceptual Data Model Nesha Catering Service and Decoration

\section{e. Diagram Konteks (Context Diagram)}

Diagram Konteks merupakan diagram yang menunjukan alur proses pada perangkat lunak secara umum. Proses-proses dan aliran data pada perangkat lunak secara keseluruhan. Disajikan pada Gamabr 5. 


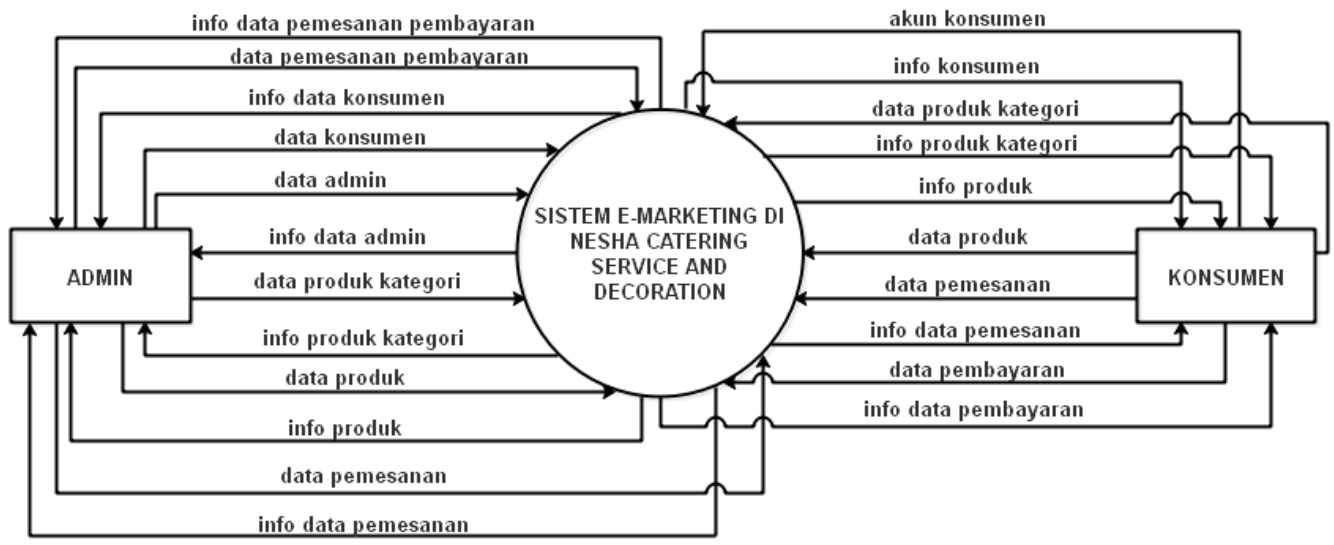

Gambar 5. Diagram Konteks

Diagram Konteks menunjukan bahwa semua aliran data yang ada menuju pada satu proses, yaitu proses Sistem E-Marketing di Nesha Catering Service and Decoration. Ada dua entitas yang terlibat di sistem ini yaitu entitas Admin dan entitas User. Masing-masing entitas memiliki data masukkan dan data keluaran pada sistem.

\section{1) DFD Level 1}

Pada DFD ini diberikan gambaran yang lebih spesifik tentang sistem. DFD level 1 ini merupakan hasil pemecahan dari Diagram Konteks. DFD level 1 disajikan pada Gamabr 6.

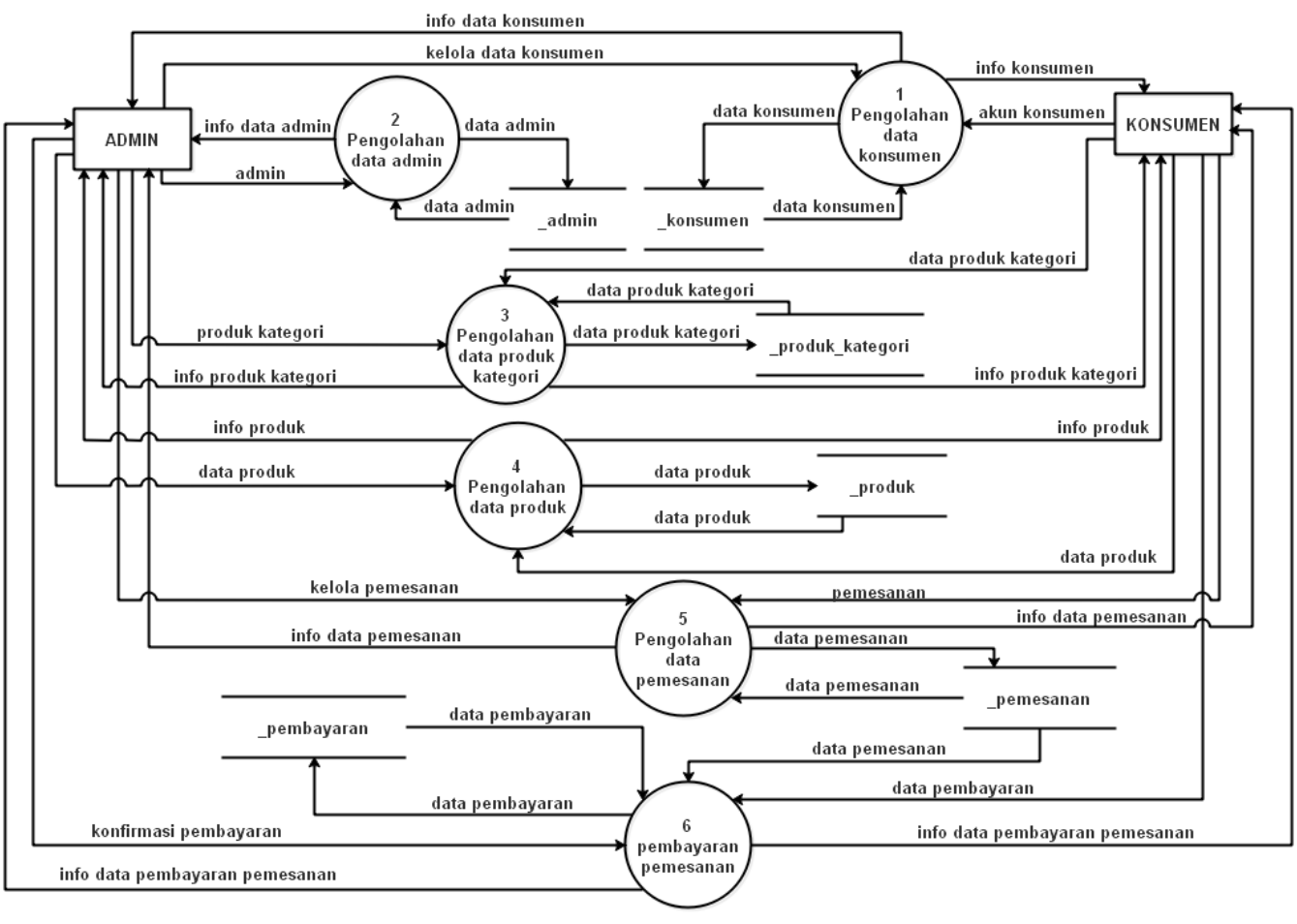

Gambar 6. DFD Level 1

DFD level 1 merupakan pengembangan dari Diagram Konteks. Didalam DFD level 1 terdapat dua entitas yaitu entitas admin dengan entitas konsumen dimana setiap entitas memiliki aliran data masing-masing. DFD level 1 ini juga memiliki enam layanan proses diantaranya adalah:

a) Proses 1, konsumen memasukan username dan password yang telah terdaftar menjadi member untuk masuk ke dalam menu utama sistem. Selanjutnya data konsumen yang di inputkan akan di proses dan di simpan ke dalam datastore_konsumen. Data store tersebut menampilkan data 
konsumen pada proses pengolahan data konsumen dan menampilkan informasi konsumsen bagi admin. Kemudian admin mengelola data konsumen yang sudah terdaftar menjadi member.

b) Proses 2, admin mengelola data pada proses pengolahan data admin yang tersimpan pada data store_admin dan menampilkan info data admin.

c) Proses 3, admin melakukan proses pengolahan data produk katergori dan memasukan data produk kategori ke dalam sistem yang di simpan ke data store _produk_kategori dan menghasilkan info produk kategori bagi admin. Selanjutnya konsumen melihat data produk kategori yang sudah di olah admin dan menampilkan info produk kategori bagi konsumen.

d) Proses 4, admin melakukan proses pengolahan data produk dan memasukan data produk ke dalam sistem yang di simpan ke data store _produk dan menghasilkan info produk bagi admin. Selanjutnya konsumen melihat data produk yang sudah di olah admin dan menampilkan info produk bagi konsumen.

e) Proses 5, Konsumen melakukan pemesanan pada proses pengolahan data pemesanan dan data pemesanan di simpan pada data store _pemesanan dan menampilkan info data pemesanan bagi konsumen. Selanjutnya admin mengelola data pemesanan pada proses pengolahan data pemesanan dan menyimpan data pemesanan ke data store _pemesanan, kemudian menampilkan info data pemesanan bagi admin.

f) Proses 6, Data store _pemesanan menampilkan data pemesanan pada proses pembayaran pemesanan, Konsumen memasukan data pembayaran yang akan di simpan di data store _pembayaran dan menampilkan info data pembayaran pemesanan bagi konsumen. Selanjutnya admin melakukan konfirmasi pembayaran pada proses pembayaran pemesanan dan menampilkan info data pembayaran pemesanan bagi admin.

Proses input konsumen antara lain input akun konsumen atau registrasi, input data pemesanan dan input data pembayaran. Selain mengimputkan data, konsumen juga dapat melihat beberapa tampilan seperti profil perusahaan, data produk, data produk kategori, cara pesan, dan kontak perusahaan guna memudahkan konsumen menggunakan perangkat lunak. Admin akan menerima data-data yang di inputkan oleh konsumen untuk memprosesnya.

\section{f. Implementasi Antarmuka}

Implementasi antarmuka menjelaskan mengenai tahapan yang harus di lakukan untuk instalasi perangkat lunak yang di hasilkan mulai dari tahapan persiapan instalasi sampai dengan perangkat lunak siap di gunakan beserta petunjuk umum penggunaan perangkat lunak per dialog screen. 


\section{HASIL DAN PEMBAHASAN}

3.1 Menu Utama

Nama Dialog Screen Menu utama/Beranda digunakan untuk menampilkan produk baru. Bentuk menu utama disajikan pada Gambar 7.

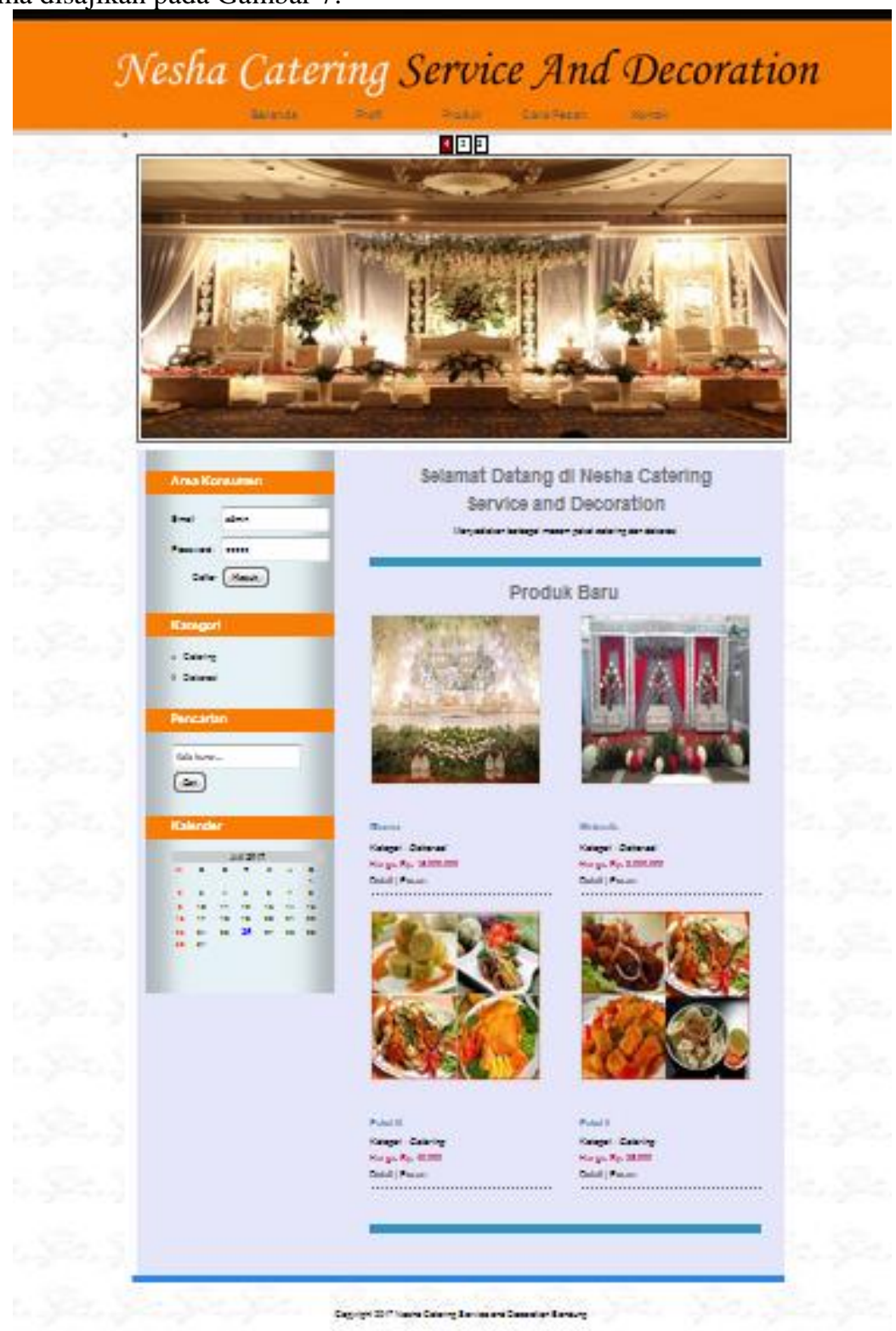

Gambar 7. Menu Utama

\subsection{Login Konsumen}

Nama Dialog Screen login konsumen digunakan untuk bisa mengakses layanan pemesanan produk. Bentuk login konsumen disajikan pada Gamabr 8.

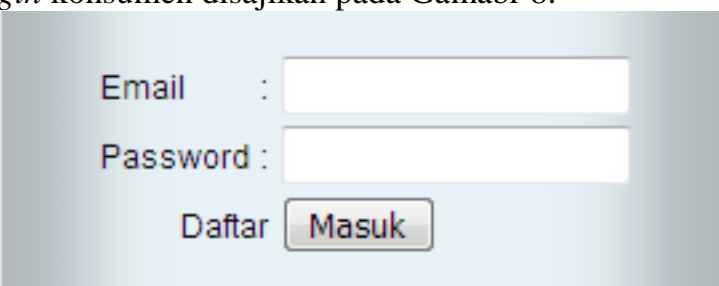

Gambar 8. Login Konsumen 


\subsection{Pendaftaran Konsumen}

Nama Dialog Screen pendaftaran konsumen untukmelakukan pendaftaran user apabila belum menjadi anggota. Bentuk pendaftaran konsumen disajikan pada Gambar 9.

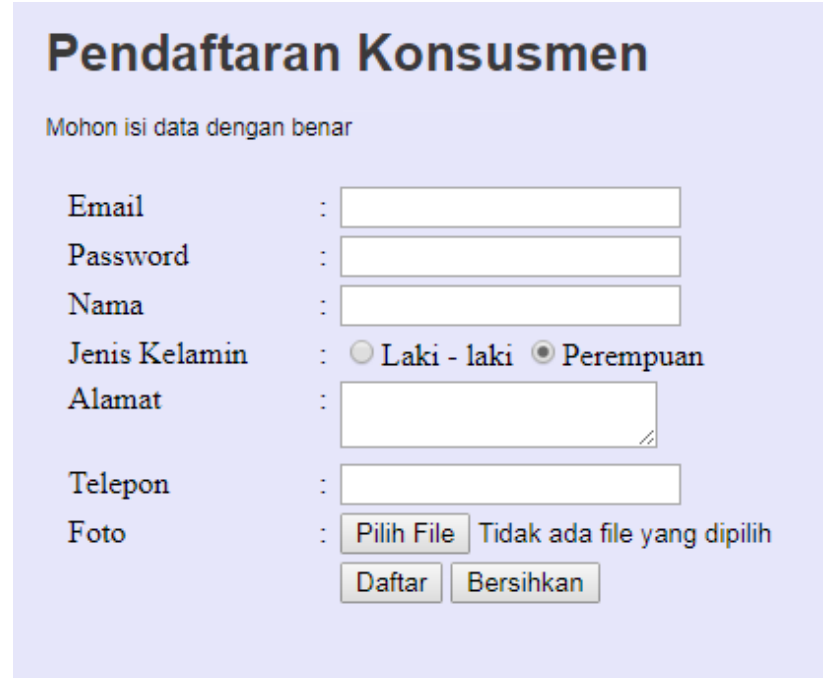

Gambar 9. Pendaftaran Konsumen

Cara penggunaan pendaftaran konsumen yaitu:

a. Masukan email dan password konsumen yang valid.

b. Masukan nama, alamat, dan no telepon konsumen dengan jelas di form isian.

c. Pilih jenis kelamin yang ada di form isian dengan klik laki-laki atau perempuan.

d. Jika konsumen ingin menambahkan foto, dapat dengan klik pilih file dan pilih foto yang user inginkan.

e. Jika semua telah terisi dengan benar klik daftar.

f. Jika konsumen ingin menghapus dan mengawali pendaftaran dari awal bisa dengan cara klik bersihkan.

g. Jika ada inputan yang tidak valid maka user diharuskan memperbaiki isian pendaftaran. Inputan yang tidak valid disajikan pada Gamabr 10.

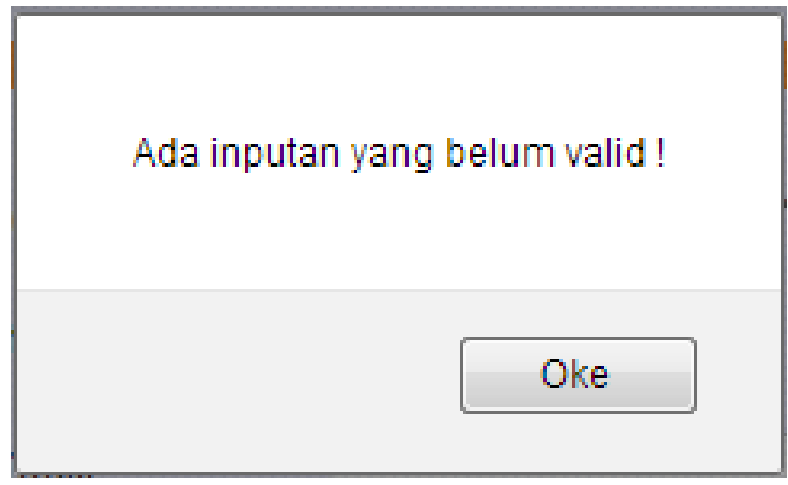

Gambar 10. Message Box Tidak Valid 


\subsection{Detail Produk}

Nama Dialog Screen detail produk untuk menampilkan detail produk. Bentuk detail produk disajikan pada Gamabr 11.

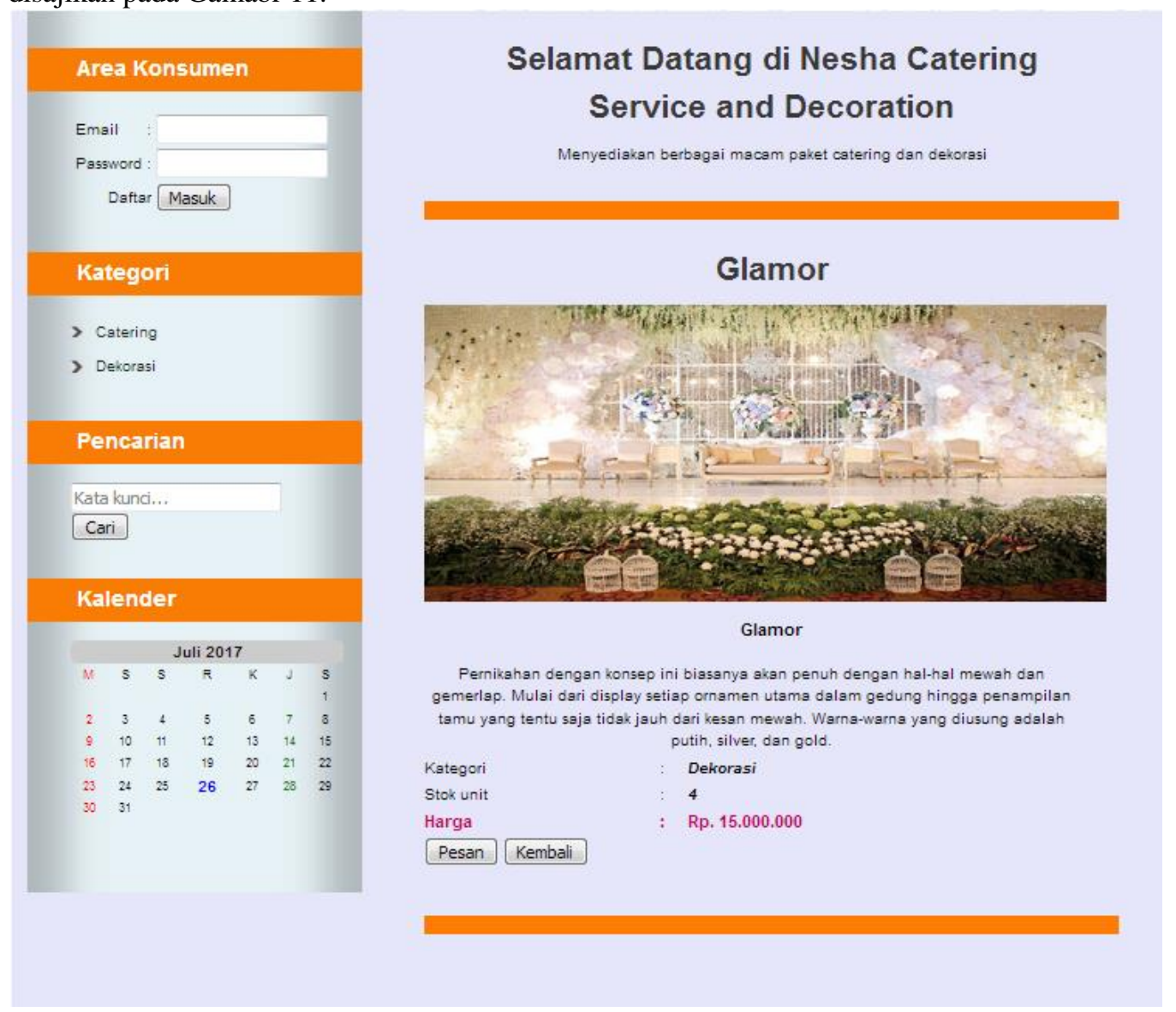

Gambar 11. Detail Produk

Cara penggunaan detail produk yaitu:

a. Klik pesan untuk melakukan pemesanan produk

b. Klik kembali untuk kembali ke menu produk 


\subsection{Data Pemesanan}

Nama Dialog Screen data Pemesanan untuk menampilkan total harga produk yang telah dipesan.

Bentuk data pemesanan disajikan pada Gambar 12.

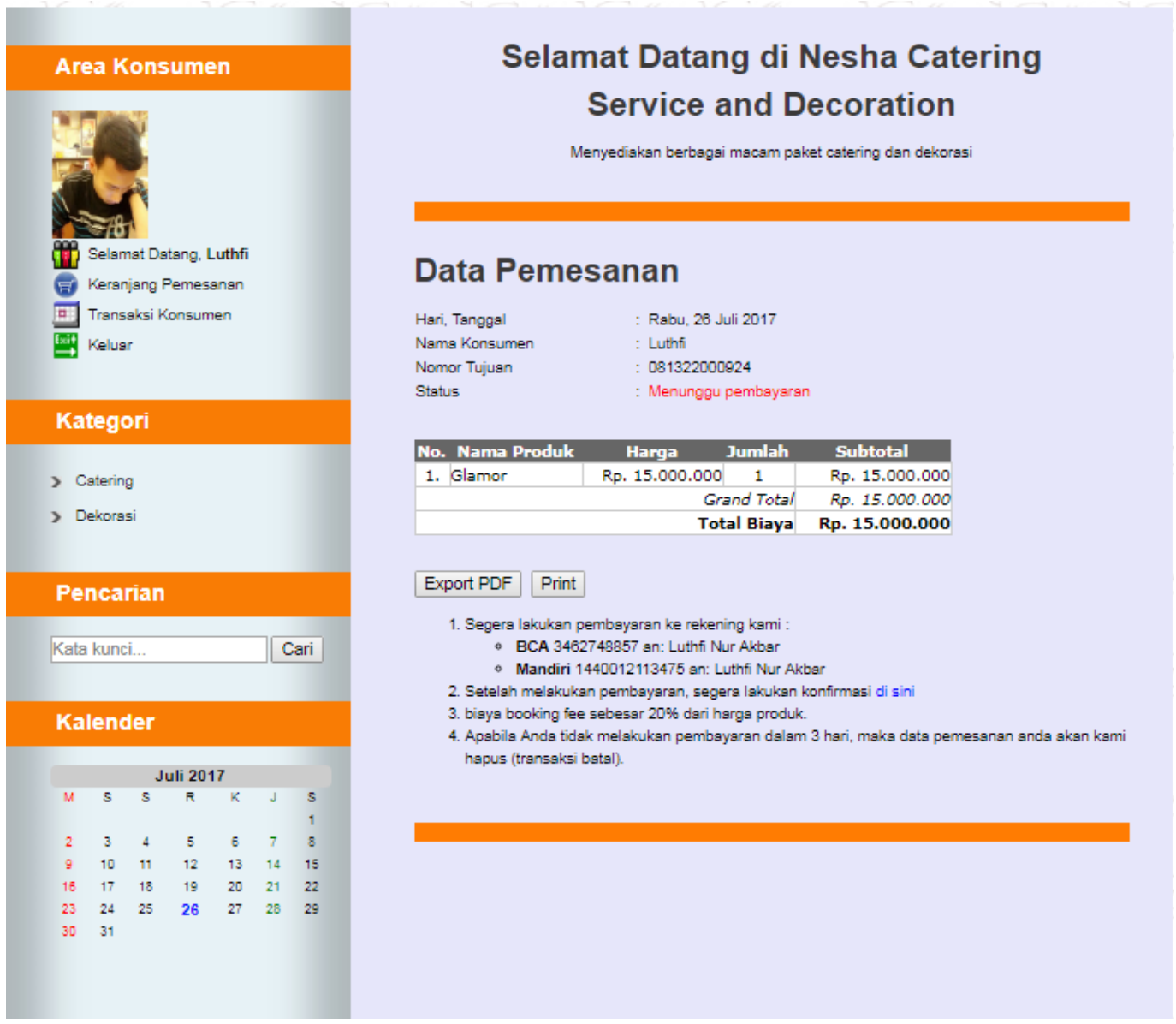

Gambar 12. Data Pemesanan

Cara penggunaan data pemesanan yaitu:

a. Klik cetak pdf jika konsumen ingin memindahkan data pemesanan ke pdf sekaligus print pemesanan.

b. Jika konsumen akan melakukan konfirmasi pembayaran klik di sini.

\section{KESIMPULAN}

Berdasarkan hasil penelitian dari analisis perancangan hingga implementasi aplikasi web sebagai strategi dalam pengembangan sistem aplikasi, maka dapat diambil kesimpulan sebagai berikut:

a. Dengan adanya perangkat lunak ini, informasi tentang produk di Nesha Catering Service and Decoration dapat terpublikasi dengan baik.

b. Aplikasi ini menyajikan informasi terkait dengan Nesha Catering Service and Decoration yang ditujukan kepada konsumen.

c. Dalam mengimplementasikan aplikasi e-marketing, strategi perencanaan yang dibuat meliputi:

1) Kekuatan dan Peluang dengan menerapkan strategy perluasan pangsa pasar dapat menggunakan fitur web seperti: Register, Tell friend, Facebook, News Letter. Untuk pelayanan, fitur web meliputi Yahoo Pingbox dan FAQ. Dan member card menggunakan fitur website New Discount

2) Pertumbuhan (Growth) dan Kompetitif dengan menerapkan strategi pengembangan pasar dengan fitur website shopping cart, tell friend. Strategi penetrasi pasar, fitur website meliputi new products, new discount, dan strategy pengembangan produk, fitur website meliputi even dan new products. 
3) Mempertahankan Pelanggan Lama dengan menerapkan strategy member card dengan fitur website new discount dan SMS Gateway dengan fitur news letter.

4) Mencari Pelanggan Baru dengan menerapkan strategy promosi dengan fitur website tell friend dan facebook, strategi member card dengan fitur website event, dan strategi discount dengan fitur website new products dan new discount.

5) Meningkatkan penjualan dengan menerapkan strategi discount dengan fitur website new discount, strategi new produk dengan fitur website new products, strategi pelayanan dengan fitur website Yahoo Pingbox dan FAQ, dan strategi promosi dengan fitur website tell friend dan facebook.

\section{REFERENSI}

1. Kotler, P., \& Amstrong, G. (2004). Principles of Marketing (10th ed.). Upper Saddle River, New Jersey: Pearson Education.

2. Mohammed, R. A., et. al. (2006). Internet marketing: building advantage in a networked economy (2nd ed.). New York: McGraw Hill.

3. Rayport, J. F., \& Jaworski, B. J. (2003). Introduction to e-commerce (2nd ed.). New York: McGrawHill.

4. Reedy, J., Schullo, S., \& Zimmerman, K. (2000). Electronic marketing, integrating electronic resources into the marketing process. United States of America: The Dryden Press, Harcourt College Publishers.

5. Strauss, J., \& Frost, R. (2009). E-marketing (5th ed.). Upper Saddle, New Jersey: Prentice-Hall. 